\title{
WETLAND PARK: AN IMPORTANT ELEMENT FOR SEWAGE RECYCLING IN KALININGRAD
}

\author{
Sergey Umansky \\ Kaliningrad State Technical University, Russia
}

\begin{abstract}
$\operatorname{ABSTRACT}$
Kaliningrad is a large industrial city with the population more than 400 thousand people that has no modern constructions for sewage treatment. Almost 100 million $\mathrm{m}^{3}$ of sewage is annually discharged into the Pregolja River and the Vistula Lagoon. City authorities have a project for constructing a full cycle of waste water treatment plant. However, the offered development plan and treatment level will not promote decreasing of eutrophication in the Vistula Lagoon. In this article the opportunity of using water plants for additional cleaning sewage of Kaliningrad has being considered. For this purpose it is suggested to organize a wetland park in a territory along the right bank of the Kaliningrad naval channel in an area with $86.6 \mathrm{~km}^{2}$. The infrastructure for such wetland-park might be used for recreational purpose too. The proposal is to consider the wetland park as an effective commercial enterprise occupying certain sector in the economy of the city. The basic requirements to organize the wetland park area are that: (1) The wetland-park area should be located nearby the mechanical and biological sewage treatment; (2) Two zones should be created, an industrial and a recreational zone; (3)
\end{abstract}

The borders of zones should be separated by natural or artificial elements of landscape, for example, forestations; (4) Economic and ecological requirements regarding the sewage management in Kaliningrad city are related to the necessity of meeting the demands of the Baltic Region, in order to solve the environmental problems of the Baltic Sea.

\section{KEYWORDS}

Eutrophication; Industrial and Recreational zones; Sewage waters; Treatment; Wetland-park.

\section{INTRODUCTION}

Analysis of accessible publications shows, that sources of biogenic substances which cause eutrophication of water objects are sewage of settlements (economic - household, industrial and storm drains) and agricultural drains (cattle-breeding, a superficial drain and drainage waters of meliorative systems) [1,2]. Dump of sewage in the Kaliningrad area includes approximately $160-180$ million $\mathrm{m} 3 /$ year, only $5 \%$ of these volumes are exposed to full cleaning (Table 1). Sewage of Kaliningrad (about 100 million in $\mathrm{m}^{3}$ ) is removed to the Pregolja River and Vistula Lagoon, where water is characterized as very polluted. Quantity indicators of anthropogenic dump of biogenic substances are resulted in Table 2 [2].

It is well known, that anthropogenic eutrophication waters is expressed in some activities, which have negative character. One historical fact is connected to this activity. Illness was accompanied by strong muscular pains which in some cases led to lethal outcomes. 
Table 1. Quantity of sewage (million $\mathrm{m}^{3}$ ) in the Kaliningrad Region [2].

\begin{tabular}{lcccc}
\hline \multicolumn{1}{c}{ Parameters } & \multicolumn{3}{c}{ Year } \\
\cline { 2 - 5 } & $\mathbf{1 9 9 9}$ & $\mathbf{2 0 0 0}$ & $\mathbf{2 0 0 1}$ & $\mathbf{2 0 0 2}$ \\
\hline Dump of sewage & 162 & 179 & 176 & 175 \\
\hline Including the polluted drains & 134 & 152 & 150 & 151 \\
\hline $\begin{array}{l}\text { The polluted drains from the common quantity of } \\
\text { sewage (\%) }\end{array}$ & 83 & 85 & 85 & 86 \\
\hline
\end{tabular}

Table 2. Dynamics of dump of biogenic substances with sewage (tons per year).

\begin{tabular}{lccccccc}
\hline Components & $\mathbf{1 9 9 6}$ & $\mathbf{1 9 9 7}$ & $\mathbf{1 9 9 8}$ & $\mathbf{1 9 9 9}$ & $\mathbf{2 0 0 0}$ & $\mathbf{2 0 0 1}$ & $\mathbf{2 0 0 2}$ \\
\hline Nitrogen & 2005.74 & 2839.36 & 2206.93 & 2401.84 & 2484.82 & 1854.64 & 1986.37 \\
\hline Phosphorous & 285.79 & 236.98 & 301.61 & 265.07 & 218.13 & 181.05 & 203.25 \\
\hline
\end{tabular}

The number of lethal outcomes makes about $1 \%$ on the long-term data. Haff-illness (juksovskaja and sartlanskaja named also) is marked only in middle latitudes. This illness is caused by toxins of seaweed [5]. Other negative effect is that "flowering" water caused the increasing of waters $\mathrm{pH}$. The alkaline water environment creates favorable conditions for development of pathogenic microflora. Flashes of cholera as a rule are dated for lake areas or sites of the rivers with slow water exchange. Anthropogenic eutrophication creates a lot of problems for operation of water intaking constructions of a city water pipe. Consequences of anthropogenic inflow of biogenic elements in reservoirs can be seen on the block diagram (Figure 1). Discharge of the unpurified sewage is the main reason for the development of eutrophication of water bodies in Kaliningrad Region. Kaliningrad is the most important supplier of biogenic substances in the region and therefore the priority direction in the protection of environment should be in reconstruction of waste waters treatment system. Project, which was made by a design institute "Lenvodokanalproyekt" together with the Swedish company "SWECO International", proposed technological scheme of waste water treatment with the complete cycle of biological cleaning. It will be built up in three stages:

Stage 1: Construction of mechanical and biological cleaning system with the processes of dephosfatation;

Stage 2: Construction of mechanical and deep biological cleaning with the processes of denitrification and dephosfotation, will make it possible to bring the quality of the expendable effluents to the requirements HELCOM;

Stage 3: Construction of mechanical deep biological cleaning with the processes of denitrification and dephosfotation and refining on the bioreactors will make it possible to bring the quality of the expendable effluents to the requirements of Russian Federation legislation. 
The analysis of project which was made by a design institute "Lenvodokanalproyekt" showed that the period the construction will be completed the concentrations of the normalized substances in the water will comprise: $\mathrm{BOD}_{5}-8 \mathrm{mg} / \mathrm{L} ; \mathrm{N}-10 \mathrm{mg} / \mathrm{L} ; \mathrm{R}-1.5 \mathrm{mg} / \mathrm{L}$. Municipal wastewater run out to river network and further to Vistula Lagoon (the Kaliningrad marine channel and the Primorskaja Bay). The quality of water in these water bodies is illustrated at the Table 3 .

Consequences anthropogenıc eutrophication

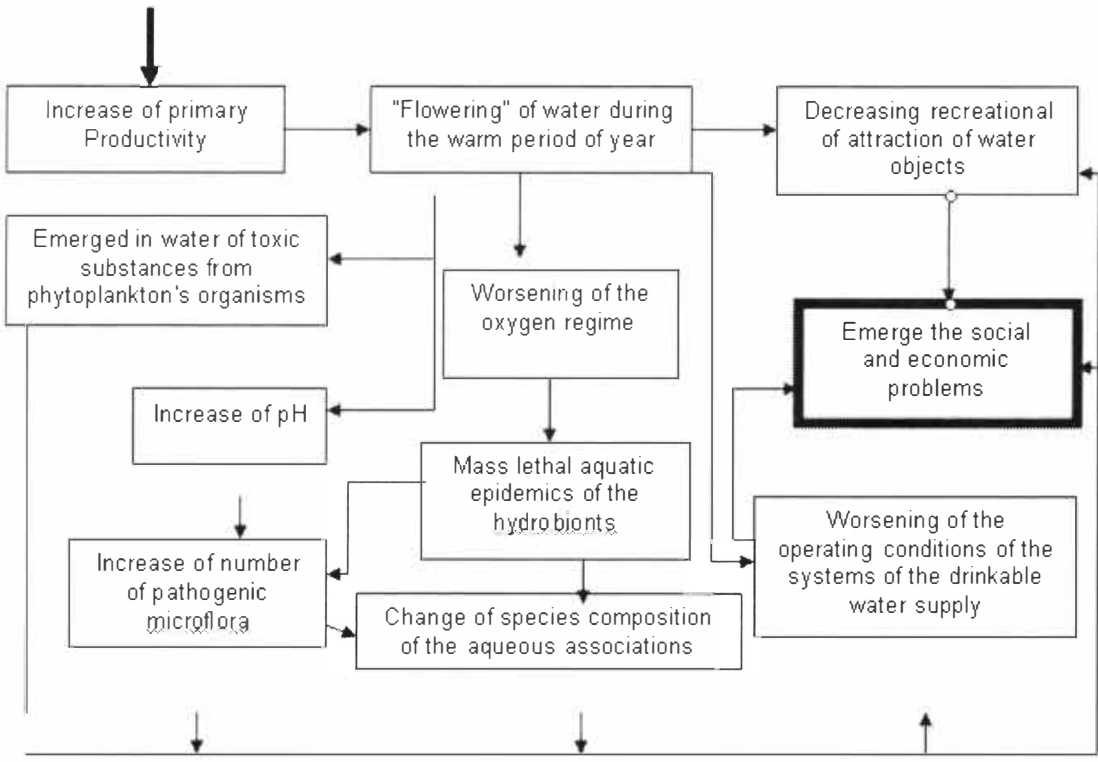

Figure 1. Consequences of anthropogenic eutrophication of waters.

Table 3. The contents of biogenic substances in sewage and water of some sites of water area Vistula's lagoon.

Concentration of substances $(\mathrm{mg} / \mathrm{L})$

\begin{tabular}{lccc}
\cline { 2 - 4 } \multicolumn{1}{c}{ Parameters } & Sewage & $\begin{array}{c}\text { Primorskaja } \\
\text { Bay }\end{array}$ & $\begin{array}{c}\text { Vistula Lagoon } \\
\text { (Kaliningrad marine channel) }\end{array}$ \\
\hline Phosphorus $\left(P()_{4}\right)$ & 3.1 & 2.9 & $0.0005-2.80$ \\
\hline Nitrogen $\left(\mathrm{NH}_{4}\right)$ & 23.0 & 23.0 & $0.18-1.91$ \\
\hline BOD & 220 & 150 & $5.6-8.9$ \\
\hline Class of water's quality & dirty & dirty & polluted \\
\hline
\end{tabular}


Table 3 shows that the main reason of high concentration of biogenic substances in the water is the discharge of sewage. Therefore the water's quality is classified as "dirty" and "polluted". Pollution of the marine channel and lagoon limits opportunities to removal sewage, which will be cleared on projected constructions. The reasons are the following:

- The contents of bioorganic substances in the marine channel and in Primorskaja Bay testify the pollution, essential reduction of a resource of auto purification and absence of an opportunity for full dilution of these municipal waters up to normative requirements.

- The ratio of the common phosphorus and the common nitrogen formed 1: 9 that specifies the presence of processes anthropogenic eutrophication [5] in Primorskaja Bay and marine channel.

- Development of actions on improvement of water quality in this water system is necessary. Results of researches on pollution tendencies of water in the Lagoon, demonstrated factors, which form secondary pollution and deteriorate ecological situation in estuary of the Pregolja River indicate on that $[3,4,5]$.

- The clean sewage before their following in the marine channel must be disinfected with the use help of chlorination. Concentration of chlorine in this water should be not less than $1.5 \mathrm{mg} / \mathrm{L}$. It will negatively influence on the hydrobionts, which will live in a zone of release of waters.

These arguments indicate that such level of wastewater treatment to reduce bioorganic substances will be insufficient. An achievement of the concentrations of bioorganic substances is technically possible. However, it would be necessary a substantial increase in the construction costs and exploitation of wastewater treatment system.

The decision of this problem is a possibility to go by application of system of sewage recycling. Sewage which has passed through a cycle of mechanical and biological treatments are used as a resource for any economic and other purposes. The analysis of experience of the European countries testifies that such approaches receive the increasing development. Use of the inconvenient boggy grounds for the organization of wetland-parks becomes a priority in sewage treatment and recycling it. As examples, the biggest artificial wetland in Sweden "Ekeby Wetland" [6] and the wetland-park Slimbridg in (UK) [7] can be mentioned. These experiences can be used for during decision process to solve the pollution of surface waters in the Kaliningrad Region.

\section{DISCUSSION}

The wetland-park can be created on the boggy grounds near to a site where new waste water treatment plant will be constructed. This territory is located along the right bank of the Kaliningrad marine channel. The general area of the territory is approximately $86.6 \mathrm{~km}^{2}$, of them $32 \mathrm{~km}^{2}$ is occupied by boggy wood, $43 \mathrm{~km}^{2}$ - thickets of aqua plants, $1.7 \mathrm{~km}^{2}$ - surface of ponds, drainage net and small river.

The author is not known in the accessible literature as a concept "wetland-park", therefore definition of this concept in author's understanding will be given below.

Wetland-park is a system of artificial reservoirs and marsh sites, which serve for stabilization of physical properties and improvement of a chemical compound of sewage, which pass through a cycle of mechanical and biological treatment. This system is intended for restoration of these waters up to parameters of ecological full value of the natural not polluted waters. This system have elements, which will allow to use resources opportunities of these 
waters for an economic proposes, satisfaction of scientific, cultural, educational and aesthetic needs.

Using this concept as a basis we shall consider the principal scheme of zoning of park's territory, which is submitted on Figure 2.

\begin{tabular}{|c|c|c|}
\hline \multicolumn{3}{|c|}{ WETLAND PARK } \\
\hline $\begin{array}{l}\text { ZONE OF SANITARY } \\
\text { PROTECTION }\end{array}$ & $\begin{array}{c}\text { ZONE OF USE OF WATER } \\
\text { RESOURCES }\end{array}$ & $\begin{array}{l}\text { ADMINISTRATIVE AND } \\
\text { THE RESIDENTIAL ZONE }\end{array}$ \\
\hline $\begin{array}{c}\text { 1. Objects of constructions of } \\
\text { mechanical and biological } \\
\text { sewage treatment }\end{array}$ & $\begin{array}{c}\text { Subzone of recreation (the basic } \\
\text { directions of recreational water use) }\end{array}$ & Subzone of office buildings \\
\hline $\begin{array}{l}\text { 2. Site of warehousing of a } \\
\text { deposit }\end{array}$ & 1. Objects water and a walking tour & $\begin{array}{l}\text { 1. Office of the managing } \\
\text { company }\end{array}$ \\
\hline $\begin{array}{l}\text { 3. Industrial wetlands for } \\
\text { additional cleaning sewage }\end{array}$ & 2. Sport fishery & $\begin{array}{l}\text { 2. Offices of the companies } \\
\text { participating in the } \\
\text { organization }\end{array}$ \\
\hline $\begin{array}{l}\text { 4. Forest shelter belt on } \\
\text { perimeter of a zone of sanitary } \\
\text { protection }\end{array}$ & 3. Rest at water and bathing & $\begin{array}{c}\text { Subzone of entertainments and } \\
\text { tourist objects }\end{array}$ \\
\hline & $\begin{array}{l}\text { Subzone of monitoring water } \\
\text { ecosystem }\end{array}$ & $\begin{array}{l}\text { 1. Hotels, bars, restaurants, } \\
\text { other objects of entertainments }\end{array}$ \\
\hline & $\begin{array}{l}\text { 1. Reserve for fauna and florae of } \\
\text { bogs }\end{array}$ & $\begin{array}{l}\text { 2. The cultural and } \\
\text { educational centers }\end{array}$ \\
\hline & 2. Research station & Subzone of habitation \\
\hline
\end{tabular}

Figure 2. Functional zoning of the wetland-park's area.

Territory of wetland-park includes three basic zones: sanitary, water resources using and administrative and residential zone. Inside a sanitary zone should be made industrial areas of wastewater treatment, slimy areas, industrial wetlands for stabilization and additional treatment of sewages, a network of the water lines (channels, pipelines, etc.) and located around of the grounds on distance which will be established by sanitary norms. On perimeter of a sanitary zone should be forest belt. Criterion of water's quality that will be flow from a sanitary zone after wetlands should be limited to requirements of sanitary norms and rules for water of recreational reservoirs.

The zone to use water resources should have the biggest territory. It is a system of natural and artificial shallow reservoirs with overgrowth of water vegetation. Reservoirs should be connected with each other by artificial network and (or) natural channels, small rivers, streams. Water from wetland-park should move to direction of the sea channel on several 
waterways and merge to channel in several points. Water plants absorb part of water and the other part evaporates. Water, passing through plants, becomes cleaner and gets properties of natural surface waters. Such water regime forms conditions for rich variety of flora and fauna. Hence, there is opportunity to use this zone as object of protection and reproduction of rare and disappearing species, which will live here. On the basis of such object there is possibility to organize a center of ecological education and to use it for ecological tourism.

Administrative and residential zone of wetland-park is to create conditions for the visitors and personnel to stay and satisfy them social, cultural, educational needs, and also for general management of this object.

The brief discussion of the scheme of functional zoning makes possible to believe, that the wetland-park can be considered as effective commercial enterprise, which will occupy the specific sector in the economy and it can serve as an element for serving the problem of the employment of City's population and Region. The merits of this project consist of the following:

- The organized discharge of the purified effluents, which will decontaminate by chlorine, will be excluded.

- Appear possibility to using resources potential of the purified effluents as a result of using the wetland-park's territory as the object of business activity (attractive for the investments of regional business-association, and also from the federal center). The project is conservation project of this scale can become the object of economic increase and attractiveness for the international investments in the development of tourism and other directions of business.

- The ecological and economic expediency of this approach is based on the need for fulfillment of commitments before the countries of Baltic Region on the solution of the eutrophication's problems of the Baltic Sea, by protection and the economical utilization of the available water resources of Kaliningrad Region.

\section{CONCLUSIONS}

The basic requirements to the organization of wetland-park's territory are here presented. (1) Nearby the wetland park territory for sewage treatment land shall not be used for agriculture, forestry or other purposes; (2) The territory of wetland-park should be divided in two zones: production zone (with the organization of the corresponding sanitary zone, including the territories of sewage treatment and wetlands) and recreational zone (water resources use). The boundaries of the zones must be divided by the natural or artificial components of landscape, for example, forestation. The recreational zone (zone to use available water resources) can include sub zones which should be distinguished by the regime of the limitations for the access of the visitors: reproduction's sub zone of animals and rare aquatic plants, sub zone of aqueous ecological tourism (ecological paths and aqueous routes), sub zone of sport's fishing and the sub zone equipped with facilities for rest: hotel, cafe and restaurants and the center of ecological education. Thus, it is possible to reach the following conclusions:

The current ecological situation in the Pregolja River, marine naval channel and the Vistula Lagoon may be characterized as critical, being the pollution of these water bodies by sewage the main reason.

The construction of biological treatment will not be able to solve this problem completely. It is necessary to carry out ecological and economic evaluation of the wetland-park as an option. 
A wetland-park system of artificial reservoirs and marsh sites, which pass through a cycle of mechanical and biological treatment, is intended for restoration of the waters up to the status. This system have elements that make possible to opportunities of these waters for an economic purpose, satisfaction of scientific, cultural, educational and aesthetic needs.

\section{REFERENCES}

[1] Доклад о состоянии и об́ охрапе окружающей среды Калининградской области в 2003 году. - Калининград, 2003. - 175 с

[2] Закономерности гидроб́ологического режима водоемов разного типа. - М.: Научный мир, 2004. - 296 с.

[3] Н.А. Богданов, А.А. Воронцов, Л.Н. Морозова. Тенденции химического загрязнения и динамика Калининградского залива. //Водные ресурсы, 2004, том 31, №5. - С. $576-590$.

[4] В.И. Сухорук, А.Ф. Кулешов Гидрофизические факторы формирования гипоксидных зон в р. Преголе. // Водные ресурсы, 2003, том 30, №6. - с. 718 728.

[5] Эволюция круговорота фосфора и эвтрофирование природных вод. - JI: Наука, 1988. - 256 c.

[6] Slimbridg's wetland-park. http//www.wetland.com

[7] Eceby wetland. - CD/ Copyright LeiLin Software, 2003. 